medRxiv preprint doi: https://doi.org/10.1101/2020.06.11.20125799; this version posted June 12, 2020. The copyright holder for this preprint (which was not certified by peer review) is the author/funder, who has granted medRxiv a license to display the preprint in perpetuity.

It is made available under a CC-BY-ND 4.0 International license .

1 Article Summary Line: We sequenced 88 genomes of SARS-CoV2 from Colombia finding 11

2 lineages and eight different introduction events

3 Running Title: Early introduction of SARS-CoV2 in Colombia

4 Keywords: COVID-19, B1, Lineage, Colombia, SARS-CoV2

5 Title: The arrival and spread of SARS-CoV2 in Colombia

6 Authors: Juan David Ramírez ${ }^{1 *}$, Carolina Florez ${ }^{2}$, Marina Muñoz ${ }^{1 \#}$, Carolina Hernández ${ }^{1}$,

7 Adriana Castillo ${ }^{1}$, Sergio Gomez ${ }^{2}$, Angelica Rico ${ }^{2}$, Lisseth Pardo ${ }^{2}$, Esther C. Barros ${ }^{2}$, Sergio

8 Castañeda $^{1}$, Nathalia Ballesteros ${ }^{1}$, David Martínez ${ }^{1}$, Laura Vega ${ }^{1}$, Jesús E. Jaimes ${ }^{1}$, Lissa Cruz-

9 Saavedra $^{1}$, Giovanny Herrera ${ }^{1}$, Luz H. Patiño ${ }^{1}$, Aníbal A. Teherán ${ }^{3}$, Ana S. Gonzalez-Reiche ${ }^{4}$,

10 Matthew M. Hernandez ${ }^{4}$, Emilia Mia Sordillo ${ }^{4}$, Viviana Simon ${ }^{4}$, Harm van Bakel ${ }^{4}$, Alberto

11 Paniz-Mondolfi ${ }^{4}$

12 Affiliations:

$13{ }^{1}$ Universidad del Rosario, Bogotá, Colombia.

$14 \quad 2$ Instituto Nacional de Salud, Bogotá, Colombia

$15{ }^{3}$ Fundación Juan N Corpas, Bogotá, Colombia.

$16{ }^{4}$ Icahn School of Medicine at Mount Sinai, New York, NY 10029, USA

17 *Correspondence: juand.ramirez@urosario.edu.co

18 \#Current address: Universidad Andrés Bello, Santiago, Chile 
medRxiv preprint doi: https://doi.org/10.1101/2020.06.11.20125799; this version posted June 12, 2020. The copyright holder for this preprint (which was not certified by peer review) is the author/funder, who has granted medRxiv a license to display the preprint in perpetuity.

It is made available under a CC-BY-ND 4.0 International license .

22 ABSTRACT (50 words)

23 We performed phylogenomic analysis of severe acute respiratory syndrome coronavirus-2

24 (SARS-CoV2) from 88 infected individuals across different regions of Colombia. Eleven

25 different lineages were detected, suggesting multiple introduction events. Pangolin lineages B.1

26 and B.1.5 were the most frequent, with B.1 being associated with prior travel to high-risk areas.

The number of severe acute respiratory syndrome coronavirus 2 (SARS-CoV2) infections is rapidly increasing throughout South America (SA). Colombia, the fifth largest country in SA is also the fifth country in number of confirmed new coronavirus disease-2019 (COVID-19)

31 cases in the region by June $8^{\text {th }}, 2020$. Following identification of the first COVID-19 case in

32 Colombia, on March 6, 2020, in a female traveler returning from Milan, Italy, the Colombian

33 government implemented early control measures. An ongoing mandatory lockdown and travel

34 ban/restriction was put in place on March 23, 2020, which included the closure of all the airports

35 across the country. Although these containment measures certainly helped reduce the basic

36 reproduction number $\left(R_{0}\right)$ from 4.8 to 2.2 , they have been unable to fully limit SARS-CoV2

37 spread in Colombia [1].

Colombia's geographic location makes it an important crossroad in the Andean region,

39 attracting many travelers across SA and making it a particular vulnerable region with important

40 implications for internal spread and dissemination to its multiple bordering countries. However,

41 in-depth studies on the molecular epidemiology and SARS-CoV2 strains circulating in Colombia

42 and elsewhere in SA are still lacking. 
medRxiv preprint doi: https://doi.org/10.1101/2020.06.11.20125799; this version posted June 12, 2020. The copyright holder for this preprint (which was not certified by peer review) is the author/funder, who has granted medRxiv a license to display the preprint in perpetuity.

It is made available under a CC-BY-ND 4.0 International license .

\section{The Study}

Individuals meeting case-definition criteria established by the Colombian Ministry of

Health and Social Protection were screened for SARS-CoV2 infection at different hospitals and

47 healthcare centers in 16 of the 32 Departments of Colombia between March $31^{\text {st }}$ and May $1^{\text {st }}$

2020 [2]. Molecular detection of SARS-CoV2 in clinical nasopharyngeal swab (NP-VTM)

49 specimens was performed using the Berlin Charité protocol [3], with 88 positive cases selected

50 for further study. Most of the SARS-CoV2 infected patients were identified in 4 (Andean,

51 Caribbean, Pacific and Orinoco) of the 6 geographic regions of Colombia; particularly in the

52 Departments of Valle del Cauca (35.9\%), Cundinamarca (11.2\%), Boyacá (10.1\%), Antioquia

$53(8.9 \%)$ and Huila (7.8\%). Sociodemographic characteristics of the 88 SARS-CoV2-positive

54 patients showed that the average age was 44 (ranging from 36-58), with $58 \%(\mathrm{n}=51)$ male and

$5542 \%(\mathrm{n}=37)$ female subjects. Different risk factors for exposure were identified, $12(13.6 \%)$

56 patients were health care workers, $55(62 \%)$ had close contact with infected patients and 23

57 (28.4\%) had traveled to high-risk areas (Mostly European countries). On presentation $17(19.3 \%)$

58 were asymptomatic, $71(80.7 \%)$ were symptomatic and $26(29.5 \%)$ required hospitalization. At

59 presentation, the most common symptoms were respiratory $(80.6 \%)$, fever (59\%) and

60 gastrointestinal symptoms (33\%). Respiratory symptoms ranged from nonspecific influenza-like

61 symptoms (dry cough and shortness of breath) to respiratory failure (5.7\%). Twenty-nine (33\%)

62 patients had concurrent conditions such as diabetes, hypertension, COPD, asthma, cardiac failure

63 and cancer.

To assess the genetic diversity and origins of SARS-CoV2 in Colombia, we sequenced 
medRxiv preprint doi: https://doi.org/10.1101/2020.06.11.20125799; this version posted June 12, 2020. The copyright holder for this preprint (which was not certified by peer review) is the author/funder, who has granted medRxiv a license to display the preprint in perpetuity.

It is made available under a CC-BY-ND 4.0 International license .

described elsewhere [4]. Comparative genome analysis of our 88 cases and 3 previously reported

67 Colombian cases was carried out relative to publicly available background data from 2,744 cases sampled from the GISAID EpiCoV database to obtain a full representation of global lineage

69 diversity [5]. Lineage assignments were performed using the Phylogenetic Assignment of Named

70 Global Outbreak LINeages tool 'Pangolin' [6]. Consensus viral sequences from each case were

71 also submitted to GISAID (accessions: EPI_ISL_447734-EPI_ISL_447817).

73 have a close phylogenetic relation to a wide range of SARS-CoV2 strains across 11 different

74 Pangolin lineages [6], with a predominance of B lineages all across the country (Fig. 1). We

75 performed univariate analysis to determine whether certain lineages were associated with a

76 health-care worker status, hospital exposure (including intensive care unit admission), or a travel

77 history to high-risk areas. A significant association $(\mathrm{p}=0.033)$ was only found between infection

78 with B.1 lineage and a travel history to high-risk areas. In conclusion, Pangolin lineage B.1 was

79 associated with prior travel to high-risk areas.

We further constructed a time-scaled ML phylogeny using TreeTime and specimen

81 collection date constraints [7]. At least nine potential introductions during the dispersion of

82 SARS-CoV2 into the country were identified between January $20^{\text {th }}$ (CI95\% Jan $18^{\text {th }}-$ Jan $\left.20^{\text {th }}\right)$ to

83 March $12^{\text {th }}\left(\mathrm{CI} 95 \%\right.$ March $\left.11^{\text {th }}-12^{\text {th }}\right)$ (Fig. 2). This suggests that SARS-CoV2 may have been

84 circulating cryptically in Colombia between late January and mid-March; up to two months

85 before confirmation of the first official case of COVID-19 by the Colombian Ministry of Health 86 and Social Protection. 
medRxiv preprint doi: https://doi.org/10.1101/2020.06.11.20125799; this version posted June 12, 2020. The copyright holder for this preprint (which was not certified by peer review) is the author/funder, who has granted medRxiv a license to display the preprint in perpetuity.

It is made available under a CC-BY-ND 4.0 International license .

\section{Conclusions}

Our data supports variable sources of introductions of the SARS-CoV2 into Colombia

91 predominantly from Europe and North America (Fig. 1), as well as active transmission despite

92 establishment of early containment measures prior to the date of the first case detected (Fig. 2).

93 Three scenarios may explain such trend. First, infected travelers and migrants from countries

94 already affected by the SARS-CoV2 likely entered Colombia prior to the travel ban and closure

95 of Colombia's borders (March $23^{\text {rd }}, 2020$ ). Second, many Colombian citizens with limited

96 economic and/or social resources have been unable to comply with quarantine measures. Third,

97 vast variations in ethnicity, climate and sociodemographic features (environmental

98 heterogeneity) across Colombia may be influencing the presentation and spread of the virus.

103 pivotal importance of genomic surveillance in epidemics and its direct implications on inferring

104 dissemination patterns. A limitation of this initial study is that we received specimens by referral 105 and did not systematically sample different regions of the country.

107 across a region with diverse and complex geopolitical and sociocultural contexts. Marked 108 poverty, urban and suburban overcrowding, scarce sanitary conditions as well as overwhelmed 109 public health systems sharply contrast with the way SARS-CoV2 has impacted most of the 
medRxiv preprint doi: https://doi.org/10.1101/2020.06.11.20125799; this version posted June 12, 2020. The copyright holder for this preprint (which was not certified by peer review) is the author/funder, who has granted medRxiv a license to display the preprint in perpetuity.

It is made available under a CC-BY-ND 4.0 International license .

110 industrialized countries of the world so far. Such conditions may negatively impact viral

111 dynamics favoring transmission and long-term persistence. In fact, the WHO has recently stated

112 that SA has now become the new epicenter of the global coronavirus pandemic, thus urging

113 implementation of widespread population surveillance and reinforcing containment measures.

Future studies in Colombia and elsewhere in SA, including sequencing of viral genomes

115 as the predicted epidemic peak approaches, and of contact cases and spread clusters, may help to

116 better identify transmission routes and inform potential prevention measures. Our study supports

117 the relevance of genomic surveillance and the critical need to establish coordinated efforts to

118 generate genomic data in SA that will enable integrative analyses to uncover SARS-CoV-2

119 dynamics at the continental level.

120

121 Acknowledgments

We thank Dirección de Investigación e Innovación from Universidad del Rosario for

123 funding this study.

\section{Author Bio}

126 Colombia. His primary research interests are genomic epidemiology and, ecology and evolution

127 of infectious diseases. 
medRxiv preprint doi: https://doi.org/10.1101/2020.06.11.20125799; this version posted June 12, 2020. The copyright holder for this preprint (which was not certified by peer review) is the author/funder, who has granted medRxiv a license to display the preprint in perpetuity.

It is made available under a CC-BY-ND 4.0 International license.

McKinney RM, Porschen RK, Edelstein PH, Bissett ML, Harris PP, Bondell SP, et al. Legionella longbeachae species nova, another etiologic agent of human pneumonia. Ann Intern Med. 1981;94:739-43.

1. Datos de Coronavirus Colombia. Ministerio de Salud y Protección Social. 2020. Website: https://www.minsalud.gov.co/salud/publica/PET/Paginas/Covid-19_copia.aspx

2. Saavedra Trujillo CH. Resumen: Consenso colombiano de atención, diagnóstico y manejo de la infección por SARS $\square \operatorname{COV} \square 2 / \mathrm{COVID} \square 19$ en establecimientos de atención de la salud $\square$ Recomendaciones basadas en consenso de expertos e informadas en la evidencia. Infectio. 2020; 24(3)

3. Corman VM, Landt O, Kaiser M, Molenkamp R, Meijer A, Chu DKW, et al. Detection of 2019 novel coronavirus (2019-nCoV) by real-time RT-PCR 2020. Eur. Surveill. 2020; 25: 2000045.

4. Gonzalez-Reiche AS, Hernandez MM, Sullivan MJ, Ciferri B, Alshammary H, Obla A, et al. Introductions and Early Spread of SARS-CoV-2 in the New York City Area. Science. 2020 May 29; eabc1917.

5. Rambaut A, Holmes EC, Hill V, O’Toole A, McCrone JT, McCrone JT, et al. A dynamic nomenclature proposal for SARS-CoV-2 to assist genomic epidemiology. BioRXiv. 2020. doi: https://doi.org/10.1101/2020.04.17.046086

6. Rambaut A, Lam TT, Carvalho LM, Pybus OG. Exploring the temporal structure of heterochronous sequences using TempEst (formerly Path-O-Gen). Virus Evol. 2016 Jan; 2(1): vew007 
medRxiv preprint doi: https://doi.org/10.1101/2020.06.11.20125799; this version posted June 12, 2020. The copyright holder for this preprint (which was not certified by peer review) is the author/funder, who has granted medRxiv a license to display the preprint in perpetuity.

It is made available under a CC-BY-ND 4.0 International license .

\section{Figure Legends}

\section{Fig 1. Distribution of several SARS-CoV2 lineages in Colombia.}

A. Maximum likelihood (ML) tree of 2,744 global background and 91 Colombian genomes (red dots; including 3 genomes previously deposited in GISAID), the tree was rooted with Pangolin coronavirus (MT084071.1). The pangolin nomenclature is used to show the eleven lineages detected in the country. B. Percentage of Colombian genomes assigned to a specific Pangolin lineage. C. Percentage of genomes from the global diversity (highlighting their geographical origin) assigned to the lineages described in Colombia using Pangolin nomenclature $\mathbf{C}$. geographical distribution of SARS-CoV2 lineages in Colombia using IQGIS. tree built in TreeTime from the trimmed whole genome alignment of the global background diversity (left). The colored dots indicate the 91 genomes encompassing the 11 lineages herein

169 described. Dots are colored according to the introductions to specific geographical regions of 170 Colombia shown on the right and labeled with numbers in the tree $($ Turquoise $=$ Tolima, Red $=$

171 Valle del Cauca, Yellow=Antioquia, Purple=Caldas and Green=Nariño). The nodes with the

172 dates estimates are indicated with the blue arrows and the number of introductions with the

173 numbers and time estimates in the table (right). The displayed time tree was inferred under a

174 strict clock model with a fixed substitution rate of $0.8 \times 10^{-3}$, based on previous rate value 
medRxiv preprint doi: https://doi.org/10.1101/2020.06.11.20125799; this version posted June 12, 2020. The copyright holder for this preprint (which was not certified by peer review) is the author/funder, who has granted medRxiv a license to display the preprint in perpetuity.

It is made available under a CC-BY-ND 4.0 International license .

175 estimates [4]. TreeTime analyses were run for a total of 6 iterations and marginal date estimates

176 of ancestral states are shown with $90 \%$ confidence intervals. 
0

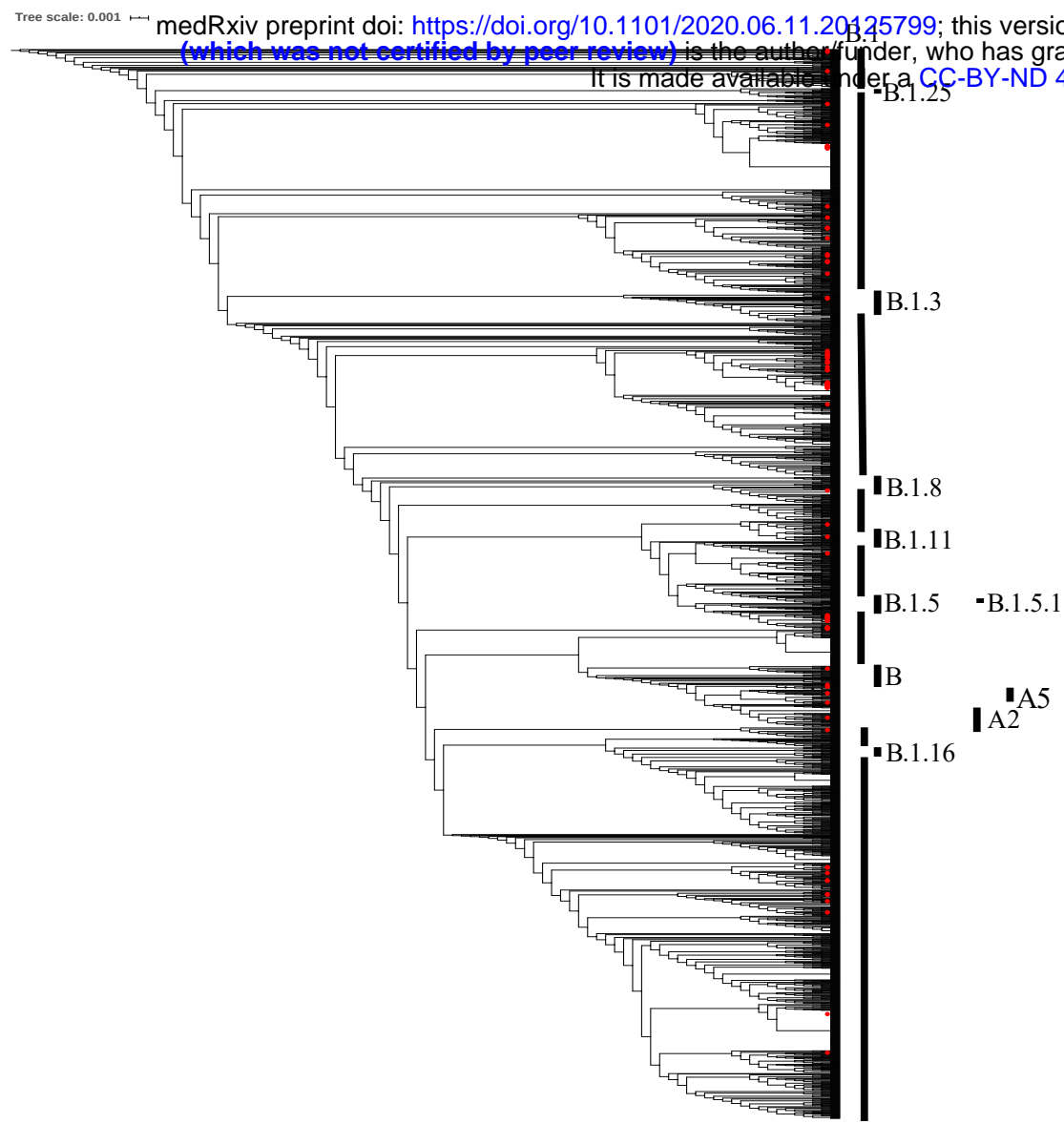

C

Global

\begin{tabular}{|c|c|c|c|c|c|c|}
\hline & & & $\begin{array}{r}\text { Gl } \\
\text { Number }\end{array}$ & $\begin{array}{l}\text { bal } \\
\text { f seque }\end{array}$ & & \\
\hline & & 500 & 1000 & 1500 & 2000 & \\
\hline B & 17 & & & & & \\
\hline B.1 & & & & & & 437 \\
\hline B.1.11 & 25 & & & & & \\
\hline B.1.16 & 18 & & & & & \\
\hline B.1.25 & 3 & & & & & \\
\hline B.1.3 & 64 & & & & & \\
\hline B.1.5 & 44 & & & & & \\
\hline B.1.5.1 & 1 & & & & & \\
\hline B.1.8 & 38 & & & & & \\
\hline A. 2 & 60 & & & & & \\
\hline A. 5 & 37 & & & & & \\
\hline
\end{tabular}

SARS-CoV-2 lineages found in this study

\begin{tabular}{|c|c|c|c|c|c|}
\hline $\mathrm{B}$ & (Austria, Belgium, Colombia, China) & B. 1.16 & (Belgium, Colombia) & B.1.5.1 & (Colombia) \\
\hline B. 1 & (USA, Belgium, France, Netherlands, & B. 1.25 & (Australia, Colombia) & B.1.8 & (Netherlands, Germany) \\
\hline & rmany, United Kingdom, Russia, Italy) & B. 1.3 & (USA, Argentina, Colombia) & A2 & (Spain, Australia, Chile) \\
\hline B.1. & (United Kingdom, USA) & B.1.5 & $\begin{array}{l}\text { (Colombia, Spain, Mexico, Taiwan, } \\
\text { United Kingdom) }\end{array}$ & A. 5 & (Spain, Uruguay, Australia) \\
\hline
\end{tabular}

D

Percentage of sequences

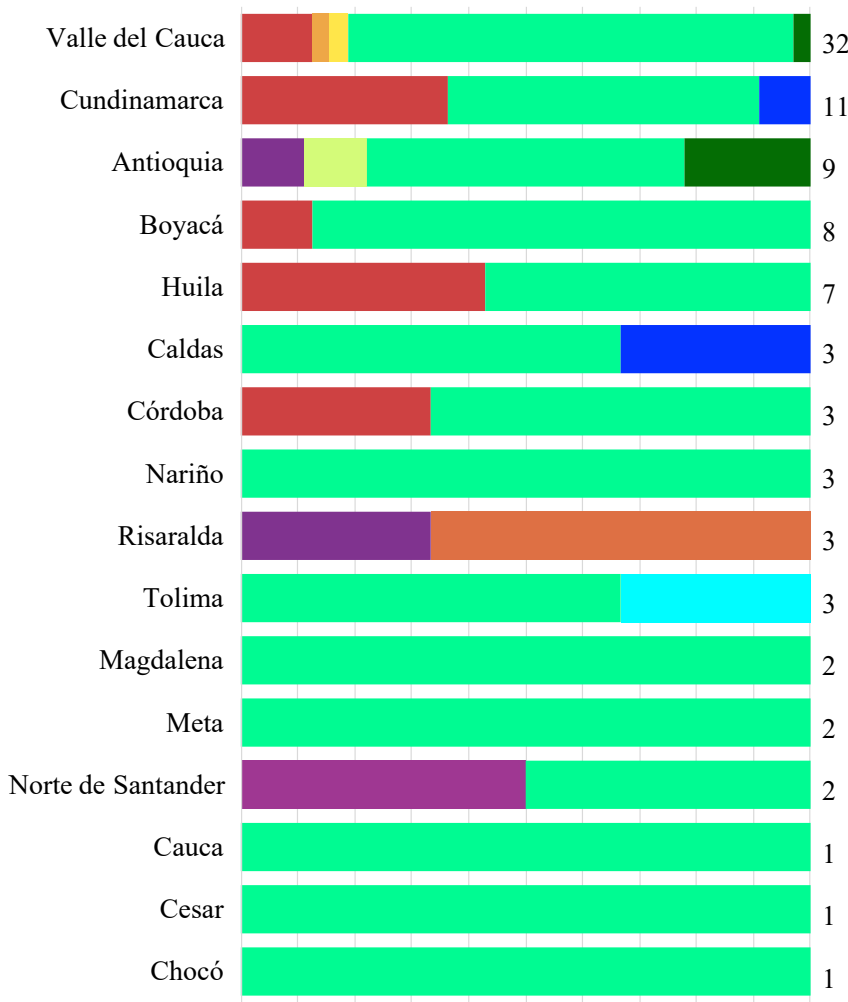

E

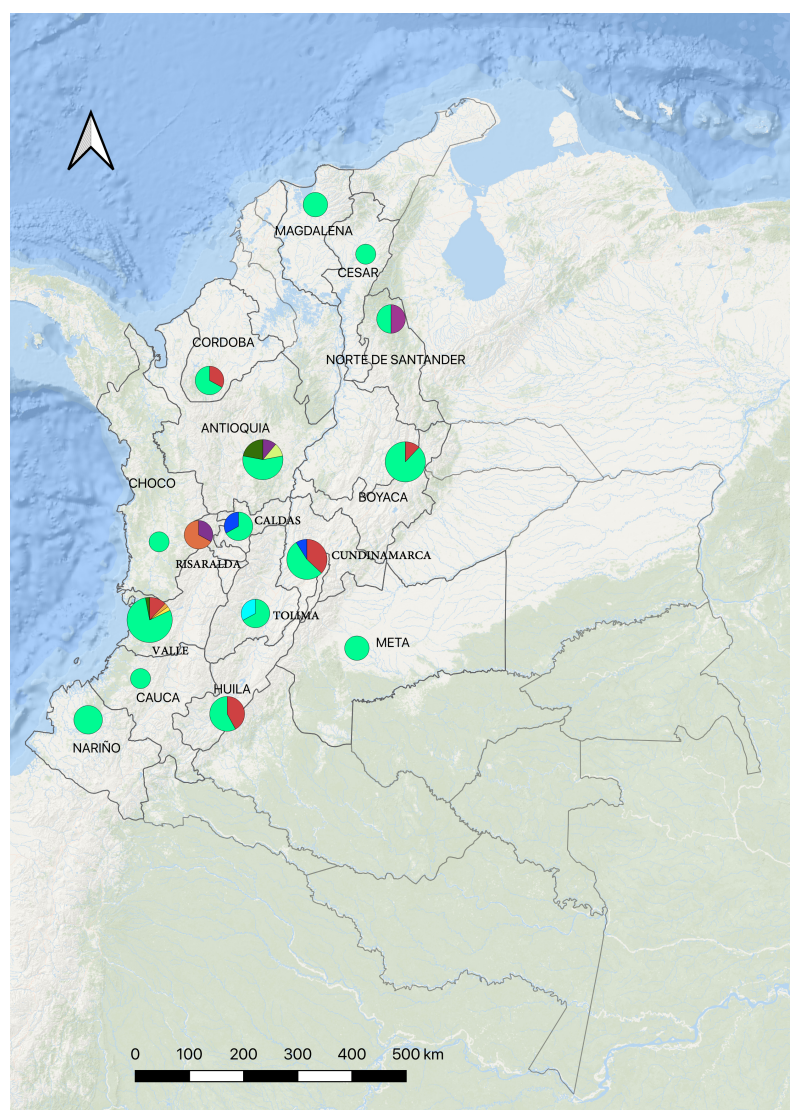



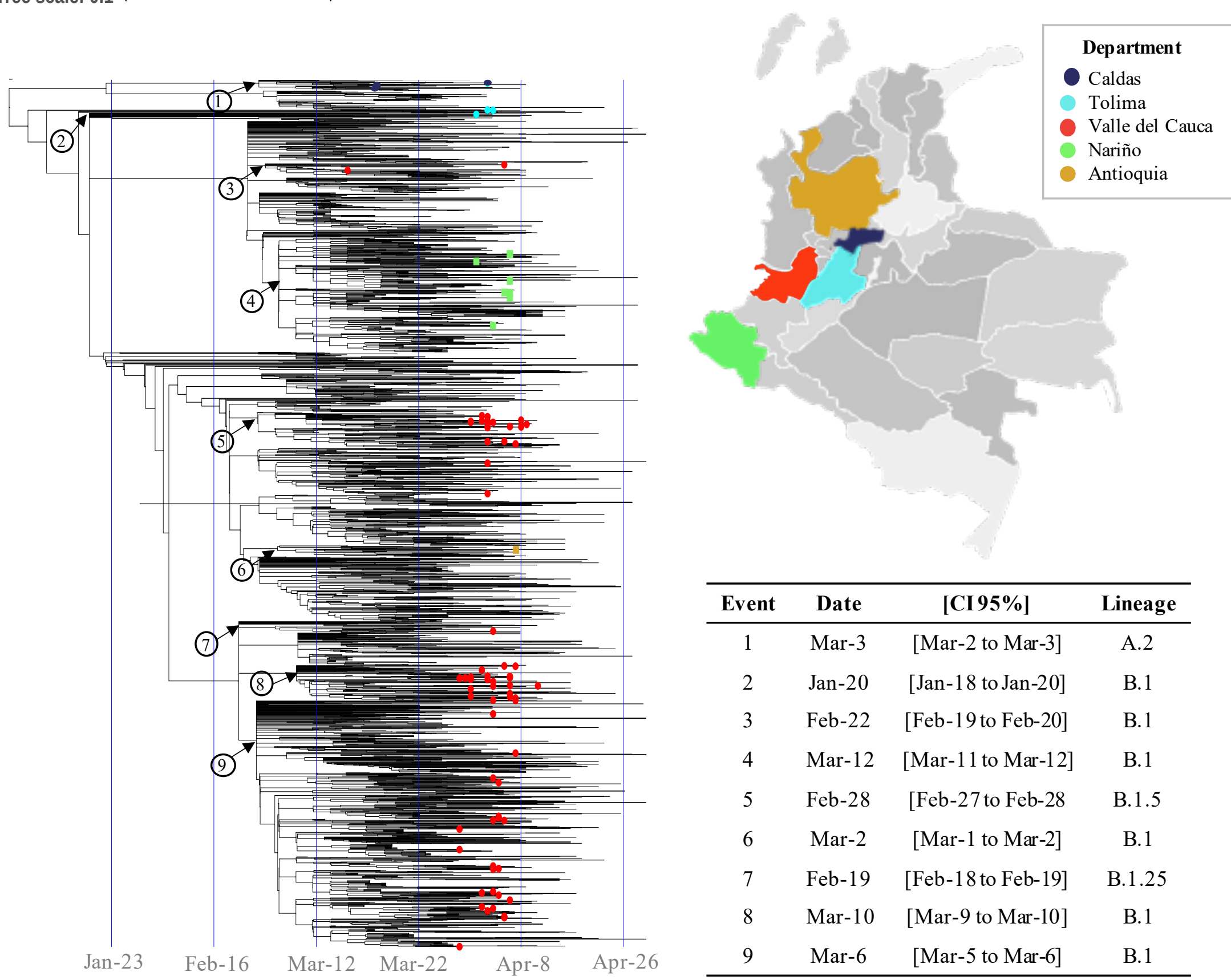